\title{
DOŚWIADCZENIA GÓRSKIE W PISARSTWIE JERZEGO STEMPOWSKIEGO
}

\author{
Andrzej SULIKOWSKI (Szczecin)
}

W eseju Nowe marzenia samotnego wędrowca czterdziestoletni autor umieszcza interesujące uwagi nt. powrotów do natury, tak modnych w kręgu cywilizacji urbanistycznej $^{1}$. Omawia tendencje europejskie, chętnie powołuje się przy tym na własny przykład. Jest „samotnym wędrowcem”, poznał już najstarszą cywilizację pasterską: po trosze z eposów Homera, po trosze z autopsji, bywając na Huculszczyźnie.

Setki pokoleń, wychowanych w jednakowych warunkach i nieprzerwanej tradycji, musiały przyprowadzić swą cywilizację do znacznego stopnia doskonałości (Nowe marzenia..., OBDR, s. 53).

Ten rodzaj cywilizacji o wszechstronnym rękodziele, znakomitej organizacji hodowli owiec i bydła, znajdujemy — dziś już reliktowo — we wsiach karpackich, a szczególnie w ubogich, wysoko położonych przysiółkach.

Pomimo swego ubóstwa góry cieszą się, wśród uciekających „,do natury”, wielkim autorytetem, właśnie dzięki zachowaniu pierwotnego wyrazu, bez żadnych retuszów (Nowe marzenia..., OBDR, s. 55).

\footnotetext{
${ }^{1}$ Pierwodruk: Marchołt 1935 nr 3; przedruk: J. Stempowski, Od Berdyczowa do Rzymu, Paryż 1971, s. 51-70 (dalej: OBDR i strona z tego wydania).
} 
Doświadczenie górskie wiąże się ze zmianą przestrzeni, do której autor przywykł. Prowadząc życie raczej miejskie, wędrując po nizinie europejskiej, Stempowski staje znienacka wobec krajobrazu pierwotnego, nierzadko nawet dzikiego. Dla każdego artysty najważniejsze są góry dzieciństwa i młodości, często stanowiące inspirację do ważnych przedsięwzięć wieku dojrzałego. Tak było w biografii twórczej eseisty, który „pierwsze sześć lat życia spędził [...] nad południowym Dniestrem, gdzie ojcu jego wyznaczono przymusowe miejsce pobytu, pod nadzorem policji”" . Południowy Dniestr, nazwa dość ogólnikowa, nie płynie w pobliżu gór, ale najbliższe - to Karpaty Wschodnie. Stąd pochodzą pierwsze wrażenia chłopięce, pierwsze przemyślenia i obserwacje młodzieńcze, powracające $\mathrm{w}$ eseistyce. Tutaj uczestniczy w starożytnej jeszcze cywilizacji Huculszczyzny i przez całe życie powraca do pomysłu wielkiej syntezy o ,starej cywilizacji rolniczej, której ślady widoczne są na Huculszczyźnie i u Kurpiów" (OBDR, s. 9).

Co oznaczają góry? Łańcuchy wysokie nieopodal doliny Dniestru (a jeszcze bardziej jego dopływów, Prutu i obu Czeremoszów, Białego i Czarnego). Pisarz już na emigracji, wędrując w 1945 roku przez Niemcy i Austrię, umieszcza w dzienniku refleksję pod datą 17 listopada. Tekst zostaje zapisany prozą, ale przy odpowiedniej lekturze głośnej nabiera znamion wyznania lirycznego:

Największą siłę magiczną posiada Czeremosz, który spośród wszystkich rzek górskich sam jeden płynie w cieniu stuletnich jodeł i świerków. Wody jego pienią się wartko w kamiennym łożysku, szemrzą na żwirowych mieliznach, dzwonią po kamieniach, bełkocą w cieśninach, huczą i dudnią w skałach, a każdemu z tych tonów, opóźniając się z lekka, wtóruje niskie, ciemne, basowe echo puszczy. Zdaje mi się, że gdybym ociemniały, stary, trawiony gorączką i obłędem, posłyszał znowu ten szum, lata błądzenia po manowcach spadłyby ze mnie jak łachmany niedoli i stałbym się znów sobą (OBDR, s. 112).

Czeremosz faktycznie przecina masyw Karpat Wschodnich, stanowiąc osobliwość geograficzną: przełom w odwiecznej puszczy. Przed wojną był granicą Rzeczypospolitej i Rumunii, rzeką spławną tylko dla najbardziej wprawnych Hucułów, którzy tędy spuszczali tratwy z pni (daraby) i kierowali surowiec w stronę Morza Czarnego (technikę tego flisu opisuje Ferdynand Antoni Ossendowski w rozdziale poświęconym Górom Czywczyńskim i Hryniawskim ${ }^{3}$ ). Cytowany fragment zawiera zdanie złożone, dźwiękonaśladowcze, doskonale zinstrumentowane w zakresie głosek i większych całostek prozodycznych. Jeśli przeczytamy je z wyczuciem rytmicznym, otrzymamy tekst o walorach minieposu, przy czym melodia — zrazu ,szeleszcząca” i „dzwoniąca” — stopniowo opada, więc można mówić o wzmocnionej, zwielokrotnionej kadencji, co jest uzasadnione, ponieważ Czeremosz płynie coraz mocniejszy, zbierając w nurt potoki górskie lewo- i prawobrzeżne:

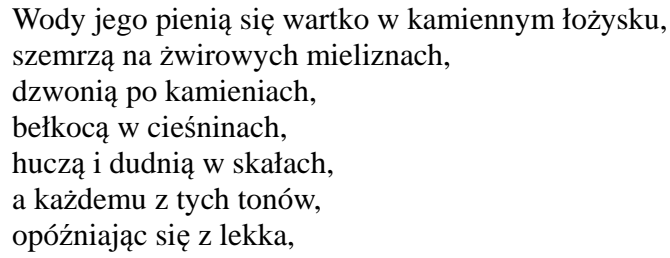

\footnotetext{
${ }^{2}$ J. Stempowski w nocie autobiograficznej odnalezionej w papierach pośmiertnych i umieszczonej jako wstęp do książki; OBDR, s. 7.

${ }^{3}$ F. A. Ossendowski, Huculszczyzna. Gorgany i Czarnohora, Poznań [1936] (opublikowana w ramach zasłużonej w okresie międzywojennym serii „Cuda Polski”).
} 
wtóruje niskie, ciemne, basowe

echo puszczy.

To część opisowa. Następuje teraz osobliwe wyznanie, mocno tkwiące w sercu Stempowskiego, powtarzane również w listach do przyjaciół. Jest to refleksja wędrowca doświadczonego, samotnego, już niemłodego, kryjąca przecież nadzieję na wewnętrzne odrodzenie. Jakieś dalekie echo przypowieści o synu marnotrawnym, jakiś ślad baśni o źródle żywej wody, przywracającej młodość i urodę. Gdyby tego nie pisał „wolterianin”, jak mawiał sam o sobie, moglibyśmy przypuścić, że powrót nad Czeremosz jest poniekąd powrotem do Domu Ojca, że ma wymiar niemal sakramentalny. W ten sposób odmładza się dusza chrześcijanina w akcie eucharystii. O takim ,sakramencie przyrody" myślał zapewne Jan Paweł II, gdy maczał dłoń w potoku tatrzańskim, czerpiąc z Siwej Wody wspomnienia lat młodzieńczych i męskich. Przeczytajmy powoli, z zastanowieniem, stawiając mocne pauzy i akcentując zestroje:

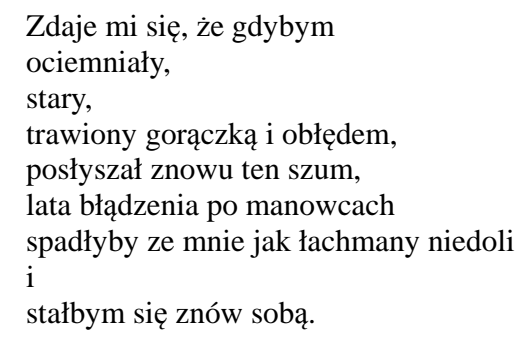

Znajdujemy tutaj inspirację Homera. Powraca tułacz doświadczony nie mniej niż Odys, znający wszystkie możliwe niedole wędrowania, a jeszcze w dodatku czujący nadchodzącą starość i spadek sił (tekst wyszedł spod pióra autora ok. 53-letniego). Słuch wydaje się zmysłem najważniejszym, wiara w samego siebie rodzi się na sposób ewangeliczny, ,ze słuchania” (fides ex auditu), co nie dziwi u pisarza, doskonale obeznanego z Ojcami Kościoła i znającego dobrze Biblię. Odzyskanie tożsamości staje się możliwe nad rzeką, przy dźwiękach płynącej wody. W całości ta znakomita sekwencja literacka wyraża jakąś pierwotną, wielką tęsknotę serca ludzkiego za całkowitym oczyszczeniem, za - by tak rzec w uproszczeniu — chrztem w rzece dzieciństwa.

Podobny wariant wyznania pojawia się w liście do Haliny Micińskiej (przyszłej żony Antoniego Kenara), datowanym w Tiszaborkut na 24 stycznia 1940 roku:

Zdaje mi się, że nawet niewidomy, stary, sparaliżowany i obłąkany, zawsze umiałbym poznać szum Czeremoszu lub Białej Cisy i odróżnić go od szumu wszystkich innych rzek; i gdybym był zaczarowany, szum ten odczarowałby mnie i zrobił znów sobą 4 .

Niewątpliwie Stempowski używa tutaj hiperboli, dopuszczając wiele klęsk na jedną osobę. Z biografii artystycznej pisarza wiadomo, że miał już wtedy za sobą dziwne i pamiętne przez dziesiątki lat doświadczenie górskie. Spróbujmy odtworzyć kolejne fazy.

Przed II wojną światową, wędrując przez Huculszczyznę, młody Stempowski obserwuje samowystarczalność tamtejszej gospodarki pastersko-rolniczej, istniejącej w górach od ,tysiącleci”. W surowym klimacie wykonuje się zawsze te same czynności, wedle rytmu agrarnego. Nie ma potrzeby się spieszyć, każda czynność sprawdzona jest od wieków, zdąży się ze wszystkim, nim nadejdą pierwsze przymrozki wrześniowe. Krótki cykl wegetacyjny musi być starannie wykorzystany.

\footnotetext{
${ }^{4}$ H. Micińska-Kenarowa, Dług wdzięczności, Warszawa 2003, s. 183.
} 
Pojawia się tutaj niepojęty wymiar czasu ponadhistorycznego, obejmującego setki lat, niezależnego od miar ludzkich i następstwa cywilizacji. Czas górski, niekiedy zwany przez wspinaczy „czasem geologicznym”, gdzie tysiąc lat jest jako jeden dzień, a jeden dzień bywa jako tysiąc lat. Nietrudno zauważyć, że ta paradoksalna definicja ma swe korzenie w Biblii i uświadamia wędrowcowi osobliwość cywilizacji górskiej, gdzie zawodzą kategorie czysto ludzkie.

Przed wybuchem II wojny Stempowski bywał w Karpatach Wschodnich ze swoją przyjaciółką, Ludwiką Rettingerową, zwaną Wichuną. Przez kilkanaście lat pisarz opiekował się chorą na nowotwór przyjaciółką i swoją serdecznością podtrzymywał gasnącą egzystencję. Pisze o tym w liście do Krystyny Marek, datowanym na 5 maja 1947:

W 1928-[19]29 postanowiłem rozejść się z piłsudczykami, nawet najumiarkowańszymi, widząc bezowocność wszelkich wysiłków dążących do zatrzymania rozpędzonej do katastrofy maszyny. [...] Na domiar złego ciążyła na mnie odpowiedzialność, której dziś nie mam, utrzymania przy życiu chorej na raka kobiety, do której byłem niezmiernie przywiązany. To utrzymanie jej przy życiu przez blisko 13 lat było moim arcydziełem, chef-d'oeuvre, capolavoro, najbardziej udanym i niewiarygodnym przedsięwzięciem, podjętym wbrew wszelkim rozumnym obliczeniom ${ }^{5}$.

Góry pojawiają się u Stempowskiego jako naturalna granica między Polską, Ukrainą, Czechami, Słowacją i Węgrami. Jednocześnie to jakby obszar wyłączony spod jurysdykcji lokalnych administracji. Prawo nie jest tutaj zbyt konsekwentnie egzekwowane, ponieważ przestrzenie są olbrzymie, ścieżki górskie wąskie, szlaki znane tubylcom, nie poddające się kontroli policyjnej i wojskowej. W każdej z krain przyległych obowiązują nieco inne ceny artykułów, a więc pojawia się możliwość przemytu. Z nielegalnych przejść leśnej granicy można czerpać pewne dochody, dlatego warto się trudzić i pokonywać wysokie, gęsto zalesione pasma.

Do przemytników Stempowski miał wielkie zaufanie jako do ludzi przedsiębiorczych, lojalnych, rozumiejących rzeczywistość górską. Przemytnik musi się wykazać nieprzeciętną inteligencją: wytyczać drogę w ten sposób, aby ominąć posterunki straży granicznej i kontroli celnej, zawczasu zbilansować swe przedsięwzięcie, opracować warianty drogi i zachowania na wypadek konfrontacji z siłami zbrojnymi. Sympatia Stempowskiego jest zawsze po stronie pojedynczego, zaradnego człowieka. Cóż, że przemytnik narusza prawo? W skali państw, wielkiej gospodarki narodowej, przemyt górski — zauważał Stempowski — stanowi znikomy procent (czy nawet promil) transakcji handlowych. Szkodliwość społeczna tego procederu była znikoma, a umożliwiała przedostawanie się przez granicę cennych produktów (lekarstw, odzieży, żywności, sprzętu turystycznego $)^{6}$. Co z punktu widzenia makroekonomii wydaje się celowe i słuszne, może być bardzo niewygodne w skali mikroekonomicznej.

${ }^{5}$ Cyt. za: W. Karpiński, Talizmany niespiesznego przechodnia, [przedm. do:] J. Stempowski, Zapiski dla zjawy oraz zapiski z podróży do Delfinatu, tekst ustalił, przełożył i posłowiem opatrzył J. Zieliński, Warszawa 2004, s. 9 (dalej: ZDZ).

${ }^{6}$ Przemyt górski dotyczy także używek, np. tytoniu czy alkoholu. Z Krupowej Hali w Beskidzie Makowskim biegnie do dziś „tabakowy chodnik” do Sidziny, służący za czasów monarchii austro-węgierskiej nielegalnemu procederowi. Jak słusznie zauważył w Rapperswilu Andrzej Dobosz, moralna ocena przemytu w XX wieku i obecnie staje się łatwiejsza w tym sensie, że zdecydowanie odrzucamy handel narkotykami i nie żywimy dla tego rodzaju przemytników najmniejszego szacunku. Stempowski miał do czynienia z ludźmi na swój sposób honorowymi. [W dniach 20-22 września 2007 r. w Rapperswilu odbyła się konferencja zatytułowana „Emi- 
Na doliny rzek karpackich Jerzy Stempowski w młodości patrzył „,Z wysoka”, $\mathrm{z}$ rozległych połonin albo $\mathrm{z}$ podniebnych płajów huculskich. Początkowo, do wieku średniego, raczej kontemplował Huculszczyznę, a swoje założenia mógł zweryfikować jesienią 1939 roku, kiedy — w ostatnich dniach września — przekradał się z Karpatów Wschodnich w kierunku Węgier i, zachorowawszy na zapalenie płuc, musiał zdać się całkowicie na uczynność przemytników z doliny Cisy. Drogę górską uciekiniera znamy dość dokładnie z prywatnej relacji samego pisarza, a następnie ze znanego eseju Księgozbiór przemytników ${ }^{7}$. Oto podstawowe motywy: po 17 września 1939 Stempowski usiłuje ze swym przyjacielem, Stanisławem Vincenzem, przekroczyć pasmo Karpat Wschodnich w kierunku południowym, chroniąc się przed NKWD. W drodze powrotnej z Węgier Vincenz zostaje zatrzymany przez patrol sowiecki, natomiast Stempowski, niezauważony, ucieka przed żołnierzami w kierunku Węgier ${ }^{8}$. Ma do pokonania pieszo ok. $70 \mathrm{~km}$, skąpe racje żywnościowe, ale przy tym — wielką wolę przetrwania. Dystans pokonuje w ciągu dwu dób, mało śpiąc, poruszając się w gorączce, nierzadko na granicy jawy i snu. Chwile drzemki w śpiworze nie przynoszą wytchnienia. Schodzi w końcu do doliny Cisy, ale silne przeziębienie nie ustępuje po zastosowaniu domowych środków. Nie pomagają masaże terpentyną, obkładanie ciała gorącymi cegłami itd. Trzeba prosić o pomoc fachową ${ }^{9}$.

W prowincjonalnym szpitalu Jerzy Stempowski znalazł się 28 października 1939 i przebywał tam — pod dobrą opieką, ale na głodowej diecie i prawie bez lekarstw przez dziewięć tygodni. Stan krytyczny trwał długo, dieta wojenna sprawiła, że pacjent zaledwie był w stanie się poruszać. Śmiertelne zagrożenie ustępowało bardzo powoli. Najskuteczniejsze w takim przypadku antybiotyki nie były jeszcze w medycynie stosowane, innych środków zaradczych brakowało.

W dzień św. Sylwestra - wspomina autoironicznie — zdałem wreszcie egzamin z chodzenia. Przeszedłem cały korytarz i po schodach wszedłem na pierwsze piętro. Tam czekał [na] mnie dr Bergman, który niespodziewanie zapytał, dokąd teraz zamierzam jechać. Pytanie to uświadomiło mi nagle, że nie ma żadnego miejsca, do którego byłoby mi spieszno (OBDR, s. 91).

Przebywa w przygranicznym zakątku Karpat, nad rzeką Cisą, gdzie przecinają się wpływy kulturowe Austrii, Czech, Słowacji, Polski, Rusi Zakarpackiej, Węgier. Jesz-

gracja. Klimat czasu - klimat ludzi. Jerzy Stempowski - Krystyna Marek”, gdzie Andrzej Dobosz miał wystąpienie pt. ,Jerzy Stempowski — portrecista” — red.]

${ }^{7}$ Pierwodruk: Wiadomości 1948 nr 3(111), s. 3, przedruk w OBDR, stąd wszystkie cytaty.

${ }^{8}$ Relację o losach współwędrowców, tzn. Stanisława Vincenza i jego starszego syna, Stanisława, zawiera wspomnieniowa książka S. Vincenza, Dialogi z Sowietami (Londyn 1966), szczególnie rozdziały początkowe. Stempowski był przekonany, że obaj panowie Vincenzowie zostali aresztowani i na zawsze przepadli w kazamatach moskiewskich. W Dialogach z Sowietami Jerzy Stempowski określany bywa przeważnie jako „,nasz przyjaciel essayista” (s. 23, 36), „polityczny myśliciel” (s. 23) lub ,znany literat z Warszawy” (s. 9). Nigdy nazwiskiem. Rozstanie ze Stempowskim we wsi Burkut-Kvasy Vincenz przedstawia następująco: ,przyjaciel [Stempowski] był do tego stopnia wzruszony, że choć uchodził za ideowego niedowiarka, zawołał czule: «Kochany panie Stanisławie, niech pana Bóg prowadzi»” (s. 48).Tymczasem Vincenz w strefie sowieckiej radził sobie dzielnie, znając biegle język rosyjski, gwary miejscowe, podejmując dyskusje z przesłuchującymi go enkawudystami. Został nawet zwolniony, razem z synem, z więzienia NKWD w Stanisławowie i w odpowiednim momencie — latem 1940 — uciekł z rodziną na stronę węgierską.

${ }^{9}$ List Jerzego Stempowskiego do ojca [dział Korespondencja], [przygotował do druku] J. S. Witkiewicz, Archipelag 1987 nr 4(43), s. 77-83. List, datowany w Bernie na 27 września 1945, stanowi cenne ogniwo literackie do interpretacji Księgozbioru przemytników. 
cze istnieje w górach wspólnota dawniejsza, austro-węgierska, habsburska, będąca dla pisarza istotną - pozytywną — sugestią co do kierunku rozwoju Europy. Stanisław Vincenz przypomina dyskusje na Przełęczy Tatarskiej, z udziałem Stempowskiego:

nasza grupka była zbyt zaciemniona troską o Lwów i o naszą ściślejszą ojczyznę Galicję wschodnią. Byliśmy federalistami i z wierności pomysłom zdrowego rozsądku uczepiliśmy się myśli o federacji środkowo-europejskiej, choć niewiele dla niej zrobiliśmy ${ }^{10}$.

W górach zaczęła się śmiertelnie niebezpieczna choroba i tam też, na południowych stokach karpackich, w samotni górskiej, przebiega z powodzeniem rekonwalescencja pisarza. Esej o księgozbiorze przemytników upamiętnia więc istotny epizod biografii: życie ocalone dzięki przypadkowo poznanym ludziom i dzięki żywotności własnego organizmu. Zarazem ostatni pobyt autora w sercu Europy Wschodniej, owego niezwykłego tworu, którego zagłady spodziewał się Stempowski w najbliższych latach z rąk Sowietów, stopniowo zdobywających i terroryzujących małe kraje przygraniczne. Po wielu latach Stempowski zdał sobie sprawę, że było to wydarzenie przełomowe w jego życiu: utracił Polskę, także możliwość powrotu do „ojczyzny ściślejszej" (Karpat Wschodnich); w połowie września zmarła Ludwika Rettingerowa i jednocześnie aresztowano przyjaciół, tzn. Stanisława Vincenza z synem Stanisławem. Po kilku miesiącach okupacji niemieckiej i sowieckiej okazało się, że znika z powierzchni ziemi formacja kulturowa, w której Stempowski wzrastał i znajdował miejsce. Tracił odbiorców dla swojej twórczości mówionej i pisanej. Wreszcie tracił na zawsze miejsce tak ważne, jak Słoboda Rungurska i Bystrec pod Czarnohorą, gdzie gościł z Wichuną na zaproszenie autora $\mathrm{Na}$ wysokiej potoninie.

W czasie rekonwalescencji „górskiej” — odwołujemy się tu znowuż do znanego eseju Księgozbiór przemytników - Stempowski zyskał potwierdzenie dawniejszych spostrzeżeń niespiesznego turysty karpackiego:

W tych okolicznościach mogłem ocenić dyskrecję, takt i życzliwość przemytników. W ich zawodzie dobre wychowanie zabrania stawiać pytania i dziwić się jakimkolwiek przygodom. W karczmie widziałem twarze życzliwe i dyskretne (OBDR, s. 93).

Spotkanie z prostymi ludźmi i zwyczajna rozmowa to dla eseisty podstawowe źródła poznania społeczeństwa. Przemytnicy wynajdują dla zdrowiejącego z wolna pisarza samotny, murowany dom. „Za czasów czeskich mieścił się w nim posterunek żandarmerii, potem schronisko turystyczne" (OBDR, 92). Dostarczają sągów drewna bukowego na opał, nawet worek książek i jedzenie. Dom ów pozostaje w niewielkiej odległości od brzegu Cisy, poniżej karczmy, gdzie rekonwalescent zjada co dzień skromne obiady i ma możliwość kontaktu ze swymi opiekunami. Dom nie cieszy się dobrą sławą u górali, wręcz przeciwnie. Tam straszy. Dlatego solidny, czteropokojowy budynek pozostaje wciąż niezamieszkany.

— W jakiej komitywie jest pan z diabłem? — zapytał mnie syn przemytnika.

- W jak najlepszej.

— W takim razie będzie panu tam dobrze (OBDR, s. 92).

Warunki rekonwalescencji to zarazem warunki prawie nieograniczonej, niespiesznej, wielogodzinnej lektury. Zupełna samotność przez cały dzień, mróz na zewnątrz w granicach minus $20-28{ }^{\circ} \mathrm{C}$. Nie zagraża pisarzowi ani policja lokalna, ani sowiecka, której macki nie sięgają jeszcze na południową stronę Karpat. U miejscowej ludności cieszy się przywilejem persona grata, choćby dzięki swej życzliwości dla prostych

\footnotetext{
${ }^{10}$ S. Vincenz, Dialogi z Sowietami, s. 19.
} 
ludzi. Czuje się więc bezpieczne w „samotnym schronie otoczonym zaspami śniegu” (OBDR, s. 92).

Nie zostaje wymieniona w eseju nazwa miejscowości. W liście do Krystyny Marek, datowanym w Muri na 2 maja 1941, czytamy:

Przed półtora rokiem w Aknaszlatina uważałem się już za umarłego i wolnego od wszystkich spraw. Ce qu'il avait à faire, es fait. Ce qu'on demandait de lui, est accompli jak pisze Duhamel w Le dépossedé. W tym stanie spędziłem koło 4 tygodni, zapoznając się praktycznie z egzystencją duchów i upiorów, całkowicie przytomny zresztą i pogodny ${ }^{11}$.

Nieco dalej osobliwe doświadczenie górskie przedstawione zostaje następująco:

Sama natura popycha nas w trudnych chwilach do pewnej dwutorowości. Kiedy po śmierci moich najbliższych przyjaciół i nieudanej wyprawie do Galicji wróciłem sam jeden do małego szpitala górskiego, moja osobowość rozszczepiła się na dwie części. Jedna część została delegowana do leżenia w szpitalu, druga pozostawała daleko, wolna i nieprzymuszona (LZZB, s. 30).

Zauważmy, że tak niezwykłe warunki klimatyczne dają Stempowskiemu możliwość przebywania w zamkniętej przestrzeni egzystencjalnej, trochę jak w świeckiej klauzurze. Ten rodzaj wyodrębnienia bohatera $\mathrm{z}$ życia społecznego znamy choćby z Czarodziejskiej góry, którą erudyta-Stempowski poznał z pewnością, wkrótce po wydaniu, a tym bardziej po przyznaniu Mannowi Nagrody Nobla (1929). Jest to przypadkowe, lecz błogosławione w skutkach odejście bohatera literackiego od dotychczasowego trybu życia. Próba określenia, co stanowi o tożsamości człowieka w trudnych warunkach, poza kontekstem powiązań zawodowych, rodzinnych, poza siatką dookreśleń socjologicznych.

Następnego dnia po moim przyjeździe, wskutek mrozu i zasp, koleje stanęły na całym Zakarpaciu na 35 dni. Wkrótce zabrakło nafty, potem świec. Samotne wieczory spędzałem w pokoju oświetlonym tylko migotaniem płomienia w niedomykających się drzwiczkach pieca. Mój stan nerwowy był wciąż zły. Po depresji przychodziło głupie rozrzewnienie i łzy. Przytomne zachowanie się wśród ludzi wymagało męczącego wysiłku (Księgozbiór przemytników, OBDR, s. 92-93).

Ma wiele czasu, aby rekonstruować historię książek przyniesionych przez przemytników. Zawartość górskiej biblioteczki poznajemy dość dokładnie. Jest tutaj przede wszystkim literatura łacińska w dobrych wydaniach - Horacy, Wergiliusz (Bukoliki i Georgiki), poezja łacińska okresu Odrodzenia. Następnie literatura hiszpańska. Wreszcie twórcy angielskiego romantyzmu: Robert Southey, Samuel Coleridge, kilka tomów Waltera Scotta.

${ }^{11}$ [J. Stempowski] P. Hostowiec, Listy z Ziemi Berneńskiej, przedmowa W. Weintraub, do druku przygotowała L. Ciołkoszowa, Londyn 1974, s. 24 (dalej: LZZB). W liście do Zygmunta Haupta wymienia się inną nazwę miejscowości: „Szedłem samotnie, głównie nocami przy pełni księżyca, walcząc z początkami zapalenia płuc, na które miałem chorować jeszcze przez trzy miesiące w Akwa Szlatina”; cyt. za: A. S. Kowalczyk, Jerzy Stempowski. Biografia eseisty, jako posłowie do: J. Stempowski, Listy do Jerzego Giedroycia, Warszawa [1991], s. 185. Miejscowość ta, położona nad Cisą w rejonie Marmaros, obecnie po stronie ukraińskiej, niedaleko od granicy z Rumunią, figuruje pod główną nazwą jako Slatina-Doly, a także — w zależności od języka - jako: Slatinske Doly, Sołotwinskie Kopalne, Akna-Szlatina, Flotin Dol. Uzdrowisko leżące na wysokości 295 m n.p.m. posiada cenne źródła wód mineralnych (solanki), stąd etymologia większości nazw. 
Sposób czytania Stempowskiego łatwo rekonstruujemy na podstawie tego i kilku innych esejów, wreszcie — korespondencji. Języki obce nie stanowiły przeszkody, od lat licealnych miał opinię i rzeczywiste sprawności poligloty. Zauważmy, że w plecaku przyniesionym przez młodego przemytnika Andrijka nie było ani jednego utworu po polsku. Stempowski obawiał się tylko, czy osłabiona w chorobie pamięć wystarczy na uruchomienie dawniej poznanych języków, szczególnie łaciny klasycznej. Jak wiadomo, głodowanie usuwa z mózgu duże połacie zasobu leksykalnego, szczególnie obcojęzycznego. Tymczasem okazało się, że sprawności intelektualne pozostały nienaruszone, co świadczy o żywotności Stempowskiego. Istniały trudności ze światłem: czytać można było w zasadzie tylko za dnia. Podsumowuje darowiznę przemytników: „Miałem więc na całą zimę najlepszego rodzaju lektury” (OBDR, s. 93).

W swej pustelni Stempowski sformułował podstawowe prawa obcowania z książką w sytuacji niezwykłej. „Czytelnik wojenny musi liczyć przede wszystkim na swoją pamięć. W końcu zostanie mu tylko to, co wyniesie w pamięci” (OBDR, s. 95). Chodzi tu o dotychczasowe lektury, umiejętności lingwistyczne, wypracowaną przez lata kulturę czytelniczą. „Czytelnik wojenny” to osobnik typowy dla XX wieku: inteligent wygnany ze swej ojczyzny, przeważnie uwięziony czy przeznaczony do niewolniczej pracy. Przedstawiciel cennej, środkowo-europejskiej formacji kulturowej, zajadle niszczonej — jak zauważa Aleksander Wat w Moim wieku — przez dwa totalitaryzmy, hitlerowski i sowiecki.

Następna część tego prawidła dotyczy książki i została sformułowana przy końcu eseju Księgozbiór przemytników. Zdanie — „książki czekają wszędzie na nadejście czytelnika" (s. 98) — wydaje się na pierwszy rzut oka truizmem. A jednak ta pozorna oczywistość jest niezmiernie optymistycznym i odkrywczym spostrzeżeniem uniwersalnym, sprawdzającym się w wielu sytuacjach i w losach rozmaitych ludzi. Przypadek górski, wcześniej omówiony, stanowi tutaj tylko punkt wyjścia. Stempowski dokumentuje wywód własnym przeżyciem i osobistymi doświadczeniami, aby uwiarygodnić narrację eseistyczną. Rozwija myśl o wędrującym czytelniku następująco:

W miejscach, gdzie na pozór trudno nawet o chleb i wino, w leśnych kryjówkach, na karczunkach, u flisaków i marynarzy, wszędzie leżą ukryte książki czekające swego czytelnika. Im wybredniejszy jest jego gust, im większe wymagania, tym rzadsza i piękniejsza czeka go lektura. Wystarczy mu tylko być zawsze sobą, upierać się hardo przy swych wymaganiach, nie kapitulować pod żadnym pozorem, być jak ów lewantyński zjadacz kawioru, żądający z uporem od swego boga ulubionej zakąski (OBDR, s. 98-99).

Stempowski używał w prasie emigracyjnej pseudonimu Paweł Hostowiec. Przez wiele lat nie znałem podchodzenia tego słowa, brzmiącego kresowo, jak z dialektu rusińskiego. Dopiero studiując mapę Karpat Wschodnich stwierdziłem, że to dawny szczyt przygraniczny w Górach Czywczyńskich, wysoki niemal na $1500 \mathrm{~m}$. Wspomniane mapy sztabowe odnalazły moje dzieci w Bieżanowie pod Krakowem, w opuszczonym bunkrze, „na łąkach”, w latach 80. minionego wieku. Mapy znajdowały się w podniszczonym mapniku wojskowym, zawinięte ponadto w zaolejony papier, dzięki temu przetrwały $\mathrm{w}$ betonowym schowku ponad 40 lat. Nieuszkodzone, czytelne w najdrobniejszych szczegółach, w skali 1:100 000, na papierze cokolwiek przejrzystym, wydane w 1933 przez Wojskowy Instytut Geograficzny w Warszawie.

Po kąpieli odtłuszczającej w delikatnym środku piorącym, po płukaniu i powolnym suszeniu (w cieniu, nigdy na słońcu), wszystkie cztery arkusze (przedstawiające Żabie, Pasmo Czarnohory, Jasieniów Górny, Białoberezkę itd.) nakleiłem na płótno, przedłużając ich żywot na kolejnych kilkadziesiąt lat. Los ofiarował mi cenne materiały kartograficzne do pisarstwa Jerzego Stempowskiego, Stanisława Vincenza, Ferdynanda 
Antoniego Ossendowskiego, Władysława Krygowskiego. Mogłem mieć przed sobą tereny „ojczyzny bliższej”, jak mówi Stempowski, obszary zabrane Polsce po II wojnie światowej i włączone do Ukraińskiej Republiki Socjalistycznej, całkowicie wasalnej w stosunku do Moskwy. Takich map nie było w księgarniach PRL, a te dostępne w atlasach geograficznych nie miały odpowiedniej skali i traktowały Karpaty Wschodnie jako jedno z wielu pasm potężnego górotworu, rozciągającego się od Czech i Polski, przez Ukrainę i Rumunię, aż do Bułgarii.

W sierpniu 1940 roku, już przebywając w Bernie, znakomity eseista zaczął prowadzić po francusku Notes pour une ombre, dziennik intymny, ,zapiski dla zjawy”, jak przekłada Jan Zieliński, choć może trzeba by mówić raczej o „zapiskach dla cienia”. Stempowskiemu towarzyszy w alpejskich, samotnych wędrówkach zmarła Ludwika Rettingerowa. Pisarz szuka prawdziwej „samotności górskiej” (używa terminu niemieckiego Bergeinsamkeit), ale ta jest trudna do osiągnięcia w górach Szwajcarii, przeciętych drogami żelaznymi:

Pomimo odległości daje się wyraźnie słyszeć odgłos pociągów linii prowadzącej przez przełęcz św. Got[t]harda, zgrzytanie tramwajów kursujących między Schwyz a Brunnen i klaksonów wojskowych samochodów. Jakże tam było daleko do niezmierzonej samotności Czywczyna. Tylko kwiaty te same: małe polne driakwie, goryczki, centurie, czartawy pospolite (ZDZ, s. 44-45).

Cytat stanowi wprowadzenie do ważnego przypomnienia: wspólnej wycieczki z Ludwiką Rettingerową w Pasmie Czywczyńskim. Okazuje się, że w osobie Wichuny skupiają się wartości ważne dla Stempowskiego, utracone w dniu 17 września: wolna Polska, rozległe Karpaty Wschodnie, przyjaźń z domem Vincenzów, najskrytsze przeżycia duchowe. Cień zmarłej symbolizuje najlepsze lata Stempowskiego w okresie przedemigracyjnym. Gdy mowa o motywach akwatycznych, pojawia się od razu przypomnienie akustyczne, szemranie Czarnego Czeremoszu albo Czarnej Cisy:

Łoskot ich wód, ostry, pieniący się i przenikliwy, odbija się echem od okolicznych lasów i powraca wzmocniony, głęboki, wzbogacony tonami niskimi i ciemnymi, podobny do odległego szumu wiatru wśród stuletnich drzew (ZDZ, s. 49).

I wreszcie przewija się w tekście Zapisków... owa słynna fraza Stempowskiego, znana nam już z Księgozbioru przemytników, powracająca też w korespondencji. Tym razem podano dokładne umiejscowienie:

Po raz ostatni słyszałem ten głęboki szept 18 października roku 1939, w pobliżu domu przemytników w Łuhach. Myślę, że nawet ślepy, stary, wypalony wszelkimi możliwymi gorączkami, sparaliżowany i obłąkany, umiałbym rozpoznać ten dźwięk, różny od szumu wszystkich innych rzek świata. Nawet umierając, gdybym go posłyszał, uniósłbym się w euforii ostatniego zrywu, żeby odejść bez żalu, pogodzony z losem (ZDZ, s. 50).

Z uwagi na trudną dostępność Zapisków dla zjawy wynotujmy najobszerniejszy fragment, opisujący wspólną, przedwojenną wycieczkę w Górach Czywczyńskich. Stempowski szuka samotności w Alpach i przy tej okazji wspomina zmarłą Wichunę. Intensywność duchowej komunikacji ze zmarłą nie jest w przypadku autora Esejów dla Kassandry czymś wyjątkowym. Można powiedzieć, że Stempowski rozumiał inne epoki i cywilizacje dzięki swej wybitnej, niemal parapsychologicznej wrażliwości. Dysponował niemałą wyobraźnią polihistoryczną i nawet, mimo deklarowanego wolnomyślicielstwa, także religijną. Rozważania o anielskim kroku wywodzą się zapewne jeszcze z młodzieńczej lektury Ojców Kościoła, natomiast uwagi biologiczne wydają się echem studiów przyrodniczych eseisty. 
To pani, droga zjawo, pokazała mi na łące różowy krwawnik, jakże podobny do tych, które widzieliśmy razem na wschodnim stoku Baby. Pewnego dnia wspinaliśmy się tym stromym zboczem, porośniętym zielskiem. Lekkim krokiem sunęła pani naprzód, maleńka na tle ogromnych gór. Zgięty pod ciężarem plecaka, prażony przez piekące słońce, męczyłem się, próbując z trudem kontrolować oddech i starając się maszerować regularnie, bez forsowania się i bez przystanków. Patrząc na pani krok, lekki, szybki i bez wysiłku, myślałem o ruchach aniołów i duchów, zadawałem sobie pytanie, do jakiego stopnia ta umiejętność chodzenia bez wysiłku wynika z tego, co w pani delikatne i anielskie. Zatrzymała się pani, uśmiechając się łagodnie, i wtedy, chcąc zyskać parę chwil wytchnienia, pokazałem pani różowy krwawnik, wyjaśniając, że ta odmiana występuje jedynie na wysokości powyżej tysiąca dwustu metrów. Teraz, na tej łące alpejskiej, czyż to nie pani mnie zatrzymała, by mi pokazać krwawnik? W pełnym słońcu pani cień był blady i przejrzysty. Zaszeptała mi pani do ucha kilka pośpiesznych słów, których sensu nie zrozumiałem. Zerwałem ten krwawnik i teraz, pisząc te słowa, mam go przed sobą (ZDZ, s. 45).

Zwraca uwagę świadome kontrolowanie oddechu przez narratora. Stempowski tak dobiera tempo podejść, by zestroić długość i częstotliwość kroków z rytmem wdechu-wydechu. Tego rodzaju praktyki zaleca z jednej strony starożytny jeszcze system jogi, a szczególnie ćwiczenia oddechowe, zwane po sanskrycku pranajama. Z drugiej strony podręczniki turystyki kwalifikowanej, publikowane na przełomie XIX/XX stulecia, czerpiąc $\mathrm{z}$ doświadczeń wytrawnych piechurów, doradzają właśnie przy forsowanych podejściach kontrolę oddechu, unikanie zadyszki, tempa nierównego lub wymuszonego, zbyt forsowanego dla organizmu. W Czarodziejskiej górze to interesujące zjawisko zauważył i mistrzowsko opisał Tomasz Mann, udzielając swemu bohaterowi doświadczeń marszu zbyt intensywnego jak na możliwości przybysza z nizin. Warto powracać do epizodu, w którym Hans Castorp stopniowo odzyskuje równy oddech i uświadamia sobie, ile niebezpieczeństw czai się w górach na lekkomyślnego mieszkańca strefy nadmorskiej.

Notabene spostrzeżenia Stempowskiego nt. koloru krwawnika nie są — z punktu widzenia botaniki — zbyt ścisłe. Ziele to kwitnie na różowo również poniżej $1.200 \mathrm{~m}$, co można łatwo sprawdzić w Karpatach Polskich.

Jakie miejsce zajęli górale karpaccy w myśleniu Stempowskiego? Znajdujemy w liście do Krystyny Marek datowanym w Muri na 17 grudnia 1941 pouczający fragment:

nie mam żadnej komunikacji z tzw. intelektualistami polskimi i nieraz bardzo się dziwię, kiedy o nich i ich debatach dowiaduję się z gazet i listów. Często natomiast widuję się z intelektualistami szwajcarskimi, francuskimi itd. a nawet, choć rzadko, z niemieckimi i dzięki temu mam pewien wgląd w położenie intelektualne zachodniej części kontynentu. Ta okoliczność zapewne jest przyczyną mego smutku i żalu, że nie zostałem, chociażby na Rusi Przykarpackiej, skąd wierni przemytnicy piszą do mnie i teraz (LZZB, s. 31).

Gdybym mógł wrócić chociażby do przemytników z Rusi Przykarpackiej, zrobiłbym to bez chwili wahania. Zresztą im także jest dziś źle i myślą, że tu jest lepiej, podobnie jak chorzy myślą, że na innym łóżku łatwiej wyzdrowieć (LZZB, s. 36).

Po wojnie Stempowski bywał w górach znacznie rzadziej, choć mieszkał w pobliżu Alp. W Dzienniku podróży do Austrii i Niemiec (Rzym 1946), odnotowuje, 9 grudnia 1945, epizod nielegalnego przejścia z Niemiec do Austrii. Znów korzysta tutaj, jak w Karpatach Marmaroskich, z usług przemytników. Unieważniono bowiem wszelkie 
przepustki, nie ma innej możliwości przekroczenia granicy. Relacja konkretna, jak u doświadczonego turysty.

Wstajemy o 4-tej z rana. Dokoła nóg okręcam ciężkie owijacze mego gospodarza i na watowaną kurtkę wkładam jego białą bluzę z kapturem. Rozdaję resztę rzeczy, płaszcz, walizkę etc. Z górskich przejść wychodzi się najczęściej jak z jaskini zbójników, bez bagażu. Zostaje mi tylko plecak a w nim śpiwór, koszula, pończochy, kilka książek, notatnik, funt chleba, pudełko smalcu, dwie cebule — podarunek przemytnika - pudełko ekstraktu z kawy i trochę cukru. Kto wie, czy w T... znajdzie się coś do jedzenia (OBDR, s. 150-151).

Sekwencja z 9 grudnia zawiera spostrzeżenia o charakterze ogólniejszym. Na zimowe przejście trzeba wychodzić grubo przed świtem. To najkrótsze dni w roku. Wszystko, co zbyteczne, należy zostawić w punkcie wyjścia, stąd inwentarz plecaka, znany każdemu zaprawionemu turyście. Przejście na drugą stronę Alp wymaga wcześniejszego „ogołocenia się” z dóbr nadmiernych. Jest przeto bliskie chorobie, a nawet umieraniu. Prowiant Stempowskiego wydaje się skąpy, odzwierciedla zasobność diarysty i sytuację gospodarki powojennej, o której pisze się zresztą znacznie więcej w Dzienniku podróży. Ubóstwo Stempowskiego czytelnik przyjmuje jako rzecz wiarygodną, zrozumiałą samą przez się, uwierzytelniającą całość tekstu.

Trasa podejścia opisywana jest z dużą znajomością topografii górskiej i terminologii alpinistycznej. To zaledwie stronica tekstu, a przecież warta wielokrotnej lektury. Po pięciu latach od doświadczeń karpackich i choroby w Akwa-Szlatina okazuje się, że Stempowski dysponuje wcale niemałym — jak na swój wiek (ukończone 51 lat) — zasobem sił i wytrzymałości. Po kilku godzinach żmudnego podchodzenia w kopnym śniegu nadal utrzymuje tempo: „Wspinamy się zakosami, powoli, równomiernie. Uważam na oddech, staram się stawiać stopy lekko i metodycznie" (OBDR, s. 151). Przed zmrokiem, czyli we wczesnych godzinach popołudniowych, młody przewodnik i dzielny eseista już schodzą ku stronie austriackiej. A przecież w górskim szpitaliku, w Nowy Rok 1940, uczył się stawiać pierwsze kroki... Sprawdza się tu przekonanie pisarza, że wola chodzenia może zmobilizować organizm nawet w bardzo trudnych warunkach. Wiadomo, że Jerzy Stempowski szukał w Alpach wytchnienia od codziennej rutyny, pragnął szerokich perspektyw, doznawał obecności osób zmarłych. Takie ślady obcowania duchowego znajdziemy w wydanych niedawno Zapiskach dla zjawy. W Szwajcarii nie brakowało gór i tutaj — podobnie jak w Karpatach Wschodnich — granice miały charakter umowny i nie stanowiły istotnej przeszkody dla niespiesznego przechodnia.

Na zakończenie znamienny fragment z listu Stempowskiego, datowanego w Bernie na 17 sierpnia 1967, do Jerzego Giedroycia. To ostatni ślad kontaktu pisarza z przestrzenią gór, na dwa lata przed śmiercią. Góry dają możliwość życia poza słowami i myśleniem, istnienia czysto wegetatywnego. W każdym razie pobyt tam, na wysokościach, powstrzymuje degrengoladę organizmu, daje Stempowskiemu nadzieję na lepsze miesiące czy lata. Tym razem obserwujemy wyłącznie powrót do zdrowia, a więc coś podobnego, jak wymarzony przez emigranta powrót do doliny Czeremoszu albo Cisy:

Kochany Panie Jerzy,

dwa tygodnie życia roślinnego w górach odwróciło bieg moich spraw w tym sensie, że zamiast toczyć się w kierunku cmentarza przybrały odwrotny kierunek. Przybyło mi wagi, ciśnienia i innych rzeczy niezbędnych do życia ${ }^{12}$.

\footnotetext{
${ }^{12}$ J. Stempowski, Listy do Jerzego Giedroycia, s. 163.
} 